Article

\title{
The Cyanotoxin BMAA Induces Heterocyst Specific Gene Expression in Anabaena sp. PCC 7120 under Repressive Conditions
}

\author{
Alexandra A. Popova ${ }^{1,2}$, Tatiana A. Semashko ${ }^{3}$, Natalia V. Kostina ${ }^{4}\left[\right.$, , Ulla Rasmussen ${ }^{5}$, \\ Vadim M. Govorun ${ }^{3}$ and Olga A. Koksharova $1,6, * \mathbb{D}$ \\ 1 Institute of Molecular Genetics, Russian Academy of Sciences, Kurchatov Square, 2, 123182 Moscow, Russia; \\ alexandra.a.popova@gmail.com \\ 2 Winogradsky Institute of Microbiology, Research Center of Biotechnology, Russian Academy of Sciences, \\ Prospekt 60 let Oktyabrya, 7/2, 117312 Moscow, Russia \\ 3 Scientific-Research Institute of Physical-Chemical Medicine, 119435 Moscow, Russia; \\ t.semashko@gmail.com (T.A.S.); govorun@hotmail.ru (V.M.G.) \\ 4 Soil Science Faculty, Lomonosov Moscow State University, Leninskie Gory, 1-12, 119991 Moscow, Russia; \\ nvkostina@mail.ru \\ 5 Department of Ecology, Environment and Plant Sciences, Stockholm University, 10691 Stockholm, Sweden; \\ ulla.rasmussen@su.se \\ 6 Belozersky Institute of Physical-Chemical Biology, Lomonosov Moscow State University, Leninskie Gory, \\ 1, 40, 119992 Moscow, Russia \\ * Correspondence: oa-koksharova@rambler.ru; Tel.: +7-917-534-7543; Fax: +7-(495)-939-0338
}

Received: 29 October 2018; Accepted: 12 November 2018; Published: 16 November 2018

\begin{abstract}
Cyanobacteria synthesize neurotoxic $\beta-N$-methylamino-L-alanine (BMAA). The roles of this non-protein amino acid in cyanobacterial cells are insufficiently studied. During diazotrophic growth, filamentous cyanobacteria form single differentiated cells, called heterocysts, which are separated by approximately $12-15$ vegetative cells. When combined nitrogen is available, heterocyst formation is blocked and cyanobacterial filaments contain only vegetative cells. In the present study, we discovered that exogenous BMAA induces the process of heterocyst formation in filamentous cyanobacteria under nitrogen-replete conditions that normally repress cell differentiation. BMAA treated cyanobacteria form heterocyst-like dark non-fluorescent non-functional cells. It was found that glutamate eliminates the BMAA mediated derepression. Quantitative polymerase chain reaction (qPCR) permitted to detect the BMAA impact on the transcriptional activity of several genes that are implicated in nitrogen assimilation and heterocyst formation in Anabaena sp. PCC 7120. We demonstrated that the expression of several essential genes increases in the BMAA presence under repressive conditions.
\end{abstract}

Keywords: BMAA; cyanobacteria; cyanotoxin; heterocyst differentiation; gene expression

Key Contribution: We discovered a remarkable new $\beta-N$-methylamino-L-alanine (BMAA) regulatory effect on cyanobacteria. This cyanotoxin induces heterocyst specific gene expression and heterocyst-like cell formation under repressive conditions in filamentous nitrogen-fixing cyanobacteria. The data obtained is important for further fundamental studies of the regulatory role of cyanobacterial secondary metabolites.

\section{Introduction}

$\beta-N$-methylamino-L-alanine (BMAA) is synthesized by many strains of cyanobacteria [1-5]. Biomagnifications of BMAA via food chains lead to toxin accumulation in brain tissues and 
neurodegeneration [6-8]. Phytoplankton BMAA synthesis [3,9-12] represents a potential threat to human health $[7,13]$. Thus, there is no doubt about the topicality of investigations of this cyanotoxin synthesis and its functional significance within producers' cells. Nevertheless, modern understanding of the regulation of BMAA synthesis and its functions in cyanobacteria is still not completed [14,15]. It is known that unicellular non-dizotrophic strains of Microcystis and Synechocystis synthesize BMAA in the course of nitrogen starvation, while the addition of ammonium or nitrate abolishes this synthesis [12,16]. Furthermore, it has been shown that BMAA may participate in regulation of chlorosis under nitrogen deprivation in cyanobacteria Synechocystis sp. PCC 6803 [17].

Currently there are only two published studies on the impact of BMAA on diazotrophic cyanobacteria. It was found out that that exogenous BMAA decreases the enzyme activity of nitrogenase in the diazotrophic strain Anabaena (Nostoc) sp. strain PCC 7120 [18,19]. Moreover, we have discovered that this cyanotoxin inhibits heterocyst formation in filamentous cyanobacteria under nitrogen deprivation [19]. To learn the reason behind the inhibition of heterocyst formation we applied quantitative polymerase chain reaction (qPCR) analysis and tested the transcriptional activity of several genes that control cell differentiation in Anabaena sp. PCC 7120 during nitrogen step-down. We discovered that addition of exogenous BMAA leads to down-regulation of het $R$ and hepA genes in Anabaena sp. PCC 7120 [19]. Both of these genes are essential for the differentiation of heterocysts [20]. BMAA also inhibits expression of gene nifH and nitrogenase enzyme activity in cyanobacteria, which already possessed mature heterocysts before BMAA treatment [19]. Based on our data, the results obtained by Downing et al. [16] can be considered from a new point of view. We can hypothesize that the enhancement of BMAA synthesis by non-diazotrophic cyanobacteria during nitrogen starvation could be an allelopathic tool against nitrogen-fixing cyanobacteria that is used to scavenge their released resources, including nitrogen. One can assume that BMAA synthesis may be used as a strategy in antagonistic interactions between different cyanobacterial species. Moreover, perhaps other representatives of marine phytoplankton, such as diatoms and dinoflagellates, that are capable of synthesizing BMAA $[1,10,11]$, could also use BMAA for competitive advantages. Of course, this assumption needs experimental verification.

However, the impact of BMAA on diazotrophic cyanobacteria in nitrogen-replete conditions remains unknown. In this study, we investigated exogenous BMAA effect on the Anabaena sp. PCC 7120 in the presence of nitrogen. We report new unexpected BMAA regulatory effect on the Anabaena sp. PCC 7120 (hereafter named Anabaena 7120). Cyanotoxin BMAA induces heterocyst specific gene expression in the cyanobacterium under repressive conditions.

\section{Results and Discussion}

\section{1. $\beta$-N-Methylamino-L-Alanine (BMAA) Induces Formation of Non-Functional Heterocyst-Like Cells in Anabaena 7120 in Nitrogen-Replete Conditions}

Anabaena 7120 forms filaments that consist of solely vegetative cells in the combined nitrogen presence (Figure 1B,D). In spite of this, BMAA addition caused the appearance of round-shaped dark cells after $48 \mathrm{~h}$ of incubation and more of them could be found later (after $72 \mathrm{~h}$ ) (Figure 1C,E). These cells did not exhibit autofluorescence of chlorophyll as do normally mature heterocysts (Figure 1A) [21-23]. In addition, rudiments of the polar bodies could be noticeable at 100-fold magnification in some cells (Figure 1C). Wherein, these heterocyst-like cells were smaller, or comparable in size to vegetative cells (Figure 1C,E), while mature heterocysts in Anabaena 7120 are usually larger than vegetative cells [24]. In addition, we previously observed that the sizes of vegetative cells slightly increase in Anabaena 7120 grown in diazotrophic conditions in the presence of BMAA [19]. The same effect of BMAA was detected in nitrogen-containing medium where the average sizes of vegetative cells were determined as $11.50 \pm 1.78 \mu \mathrm{m}^{2}$ and $15.27 \pm 3.23 \mu \mathrm{m}^{2}$ in the untreated and BMAA-treated samples, respectively. The mean sizes of heterocyst-like cells were $11.13 \pm 3.85 \mu \mathrm{m}^{2},(p<0.05)$. 

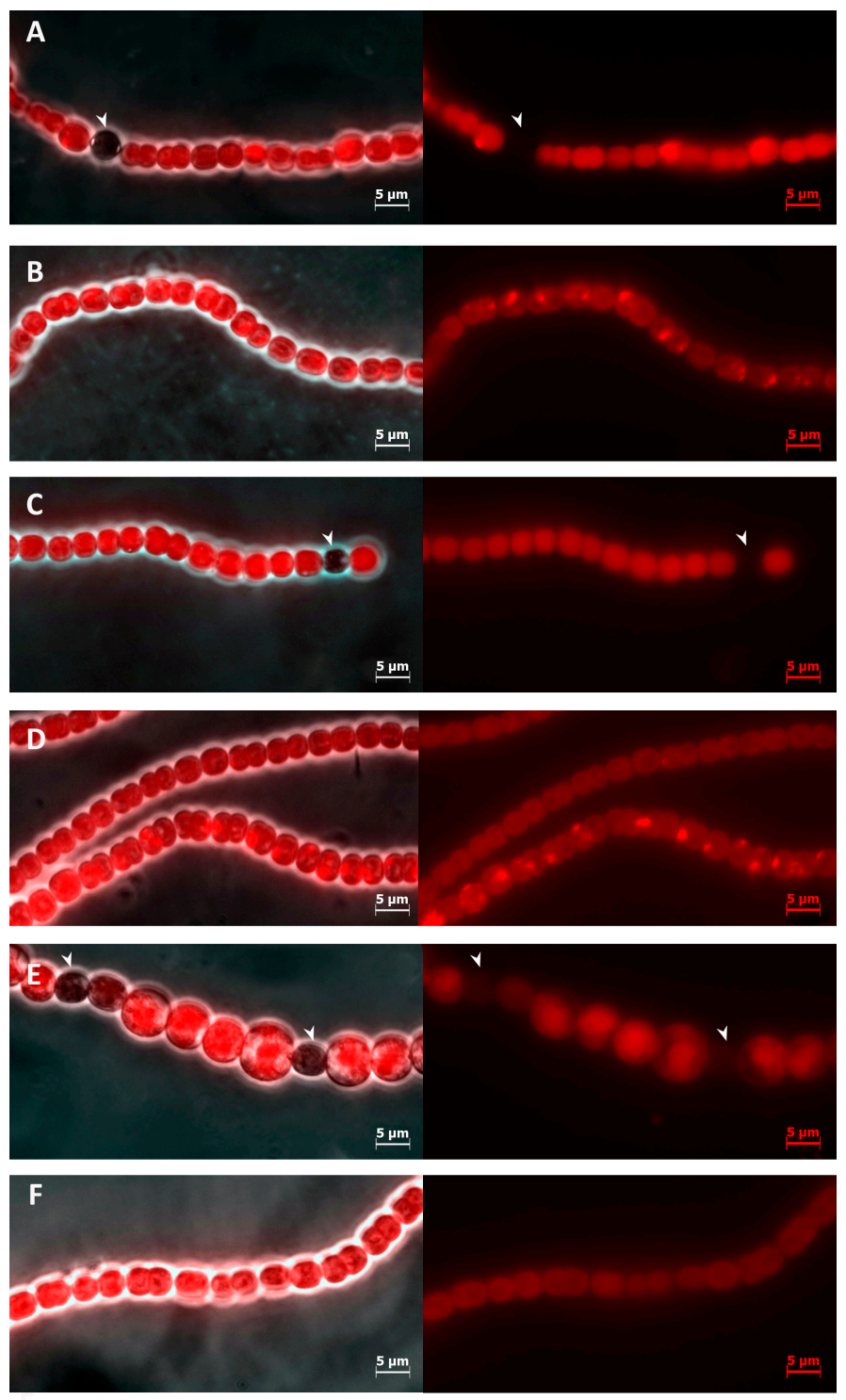

Figure 1. Filaments of Anabaena 7120 on different nitrogen sources after $72 \mathrm{~h}$ of cultivation are shown. (A) Anabaena 7120 grown on $\mathrm{BG}_{1} 1_{0}$; (B) Anabaena 7120 grown on $\mathrm{BG} 11_{\mathrm{N}}$ with $17 \mathrm{mM}$ sodium nitrate; (C) Anabaena 7120 grown on BG11 ${ }_{\mathrm{N}}$ with $17 \mathrm{mM}$ sodium nitrate and $20 \mu \mathrm{M}$ BMAA; (D) Anabaena 7120 grown on BG11 $1_{\mathrm{N}}$ with $5 \mathrm{mM}$ ammonium chloride; (E) Anabaena 7120 grown on BG11 $\mathrm{N}$ with $5 \mathrm{mM}$ ammonium chloride and $100 \mu \mathrm{M}$ BMAA; (F) cyanobacteria after $72 \mathrm{~h}$ of incubation with $20 \mu \mathrm{M}$ BMAA and $250 \mu \mathrm{M}$ glutamate on nitrate-containing medium. On the left panels, cyanobacterial filaments are shown as a combination of light field and fluorescent images. The right panels show autofluorescence of chlorophyll. Heterocyst-like cells do not show fluorescence (arrows).

We estimated the presence and frequency of heterocysts and heterocyst-like cells in Anabaena 7120 cultures grown for $72 \mathrm{~h}$ in three different conditions: (1) in nitrate-containing medium (BG11 $\left.1_{\mathrm{N}}\right)$ (only vegetative cells present in the culture) (2) in nitrate-containing medium (BG11 ${ }_{\mathrm{N}}$ ) with $20 \mu \mathrm{M}$ BMAA added (heterocyst-like cells present in the culture); (3) in nitrogen-free medium (BG11 ${ }_{0}$ ) (mature functional heterocysts present) (Figure 1, Table 1). 
Table 1. The effect of BMAA on the frequency of heterocyst and heterocyst-like cells and on nitrogenase activity of Anabaena 7120 .

\begin{tabular}{cccc}
\hline Growth Condition & $\begin{array}{c}\mathbf{1} \text { Frequency of Heterocyst or } \\
\text { Heterocyst-Like Cells, } \mathbf{1} \%\end{array}$ & $\begin{array}{c}\mathbf{2} \text { Nitrogenase Activity, } \\
\mathbf{2} \text { nmol (Eth)/ } \mathbf{\mu g}(\mathbf{C h l )} \mathbf{h}\end{array}$ \\
\hline 1 & BG11 & 0.0 & 0.0 \\
2 & $\mathrm{BG}_{\mathrm{N}}, 20 \mu \mathrm{M}$ BMAA & $3.73 \pm 1.73$ & 0.0 \\
3 & $\mathrm{BG} 11_{0}$ & $5.14 \pm 1.28$ & $22.4 \pm 3.84$ \\
\hline
\end{tabular}

${ }^{1}$ Heterocysts and heterocyst-like cells frequency expressed in \% of a total number of heterocysts and vegetative cells determined by fluorescence microscopy. ${ }^{2}$ Nitrogenase activity was expressed as chlorophyll-normalized production of $1 \mathrm{nmol}$ of ethylene per hour; Eth-ethylene, Chl—chlorophyll. The average values of three independent experiments for each experimental condition are presented. Frequency difference is significant for the condition (2) and the difference in nitrogenase activity is significant for the condition (3) in accordance with independent $t$-test $(p<0.05)$.

The frequency of heterocyst-like cells was approximately $3.73 \% \pm 1.74 \%$ after $72 \mathrm{~h}$ of incubation in liquid medium containing nitrate and $20 \mu \mathrm{M}$ BMAA that was significantly different from the untreated nitrate-grown cells (Table 1). Doubled and multiple adjacent heterocyst-like cells were also observed in the presence of BMAA (Figure 2). Note, that filaments of Anabaena 7120 grown with nitrate survived only at $20 \mu \mathrm{M}$ BMAA, while cyanobacterial filaments grown in medium with ammonium could stand concentrations of BMAA up to $200 \mu \mathrm{M}$. Furthermore, with the increase of BMAA concentration, the heterocyst-like cell frequency also increased (Figure 3).

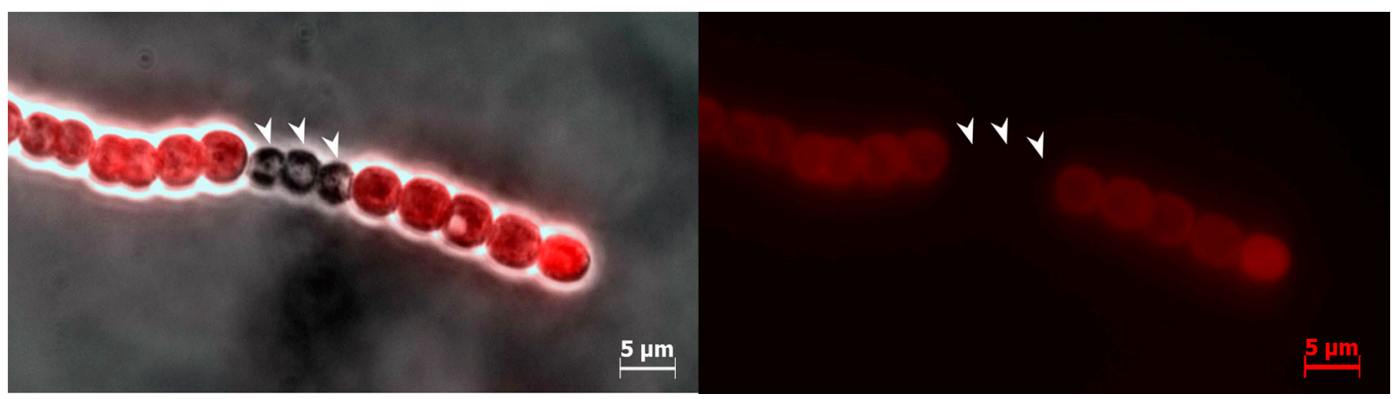

Figure 2. Anabaena 7120 filaments with multiple heterocyst-like cells after $72 \mathrm{~h}$ of cultivation on nitrate with BMAA $(20 \mu \mathrm{M})$ are presented. On the left panel, cyanobacterial filament is shown as a combination of light field and fluorescent images. The right panel shows autofluorescence of chlorophyll. Heterocyst-like cells are nonfluorescent (arrows).

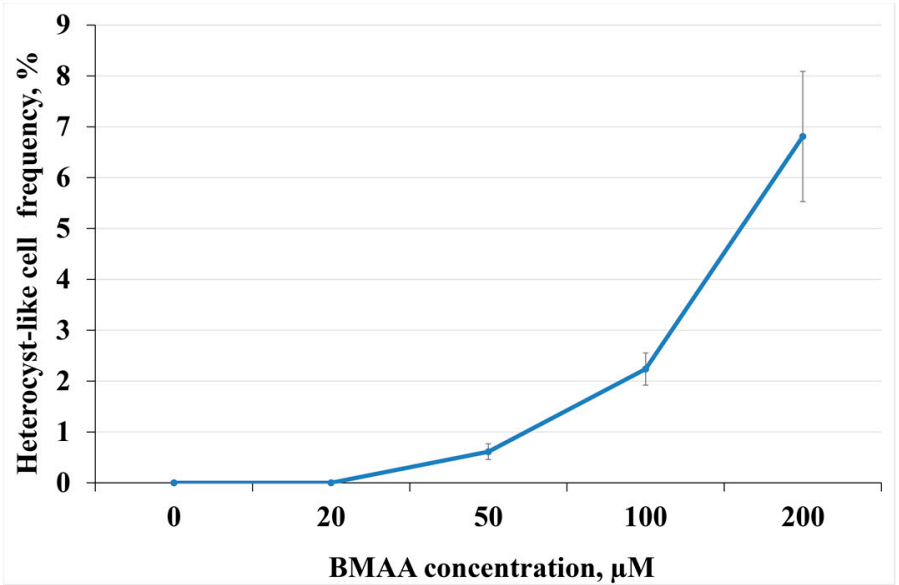

Figure 3. Dependence of heterocyst-like cells frequency on BMAA concentrations is shown. Anabaena 7120 cells were exposed with BMAA for $72 \mathrm{~h}$ in the medium containing ammonium (5 $\mathrm{mM}$ ) (as nitrogen source). 
BMAA induces heterocyst-like cells formation under nitrogen-replete conditions in symbiotic diazotrophic cyanobacteria: Nostoc sp. strain 8963 (Figure 4) and Nostoc punctiforme PCC 73102 (data not shown). As we found previously, these Nostoc strains could be exposed to higher BMAA concentrations than Anabaena 7120 [19], so we treated the Nostoc strains with $100 \mu$ M BMAA (Figure 4).
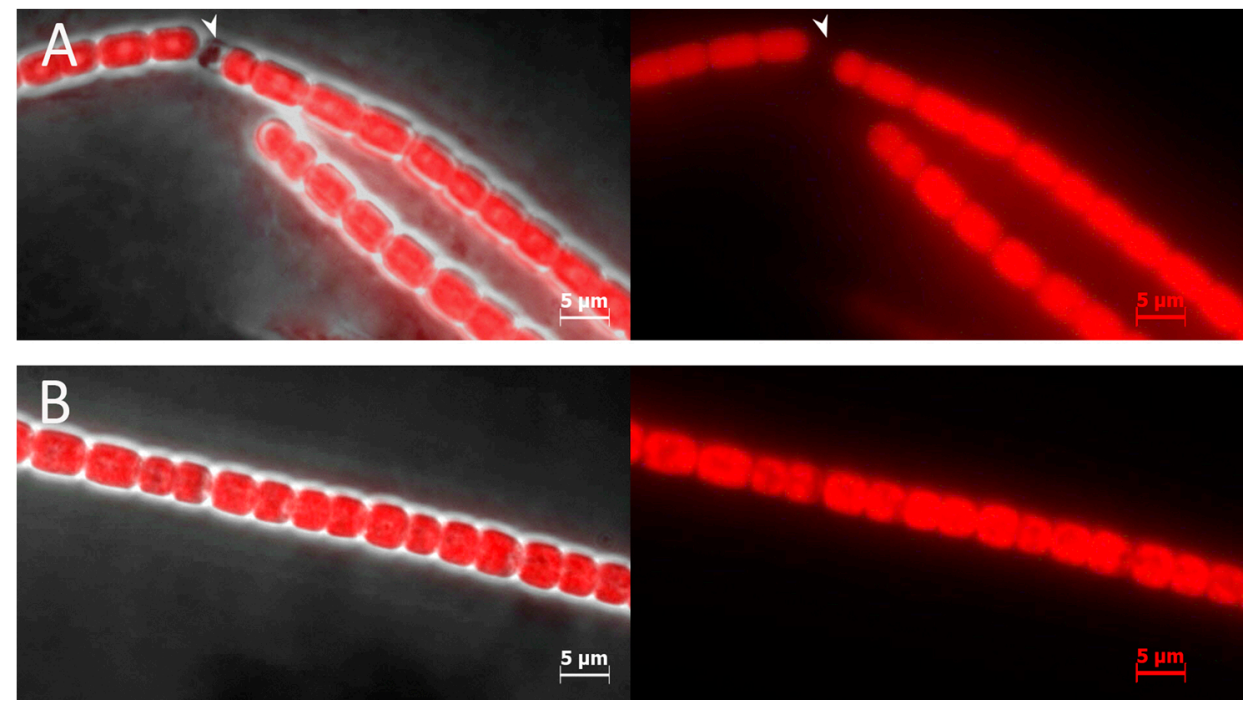

Figure 4. Filaments of Nostoc sp. strain 8963 after $72 \mathrm{~h}$ of cultivation on nitrate-medium are presented. (A) Nostoc sp. strain 8963 with $100 \mu$ M BMAA treatment; (B) Nostoc sp. strain 8963 without BMAA treatment. On the left panels, cyanobacterial filaments are shown as a combination of light field and fluorescent images. The right panels show autofluorescence of chlorophyll. Heterocyst-like cell does not show fluorescence (arrows).

The derepression effect of BMAA is eliminated by the addition of glutamate (Figure 1F). This observation is consistent with the recent results [19], which have demonstrated that glutamate eliminates repressive activity of BMAA on cell differentiation under nitrogen starvation. This agrees with a consideration that BMAA and its carbamate are glutamate receptor agonists [25].

To determine the functionality of heterocyst-like cells we used the acetylene reduction assay (ARA) [26] to measure nitrogenase activity in Anabaena 7120 that possesses heterocyst-like cells, which have appeared after BMAA treatment of culture in the growth medium BG11 $1_{\mathrm{N}}$ (Table 1). As control samples two cultures of Anabaena 7120 incubated in medium with nitrate $\left(\mathrm{BG} 11_{\mathrm{N}}\right)$ and in medium without nitrogen (BG11 0 ) (Table 1 ) were used. There was no nitrogen fixation activity in the cyanobacterial culture containing heterocyst-like cells (BG11 ${ }_{N}, 20 \mu \mathrm{M}$ BMAA) (Table 1). Thus, it can be concluded that the heterocyst-like cells are not functionally heterocysts.

\subsection{Comparison of BMMA and Other Non-Proteinogenic Amino Acids Effects on Heterocyst Derepression}

The effect of BMAA on nitrogen-grown Anabaena 7120 had similarities and differences in comparison with other non-proteinogenic amino acids that are well-known to induce derepression of heterocyst differentiation. Among them are L-methionine sulfoximine (MSX), 7-azatryptophan (azaTrp) and beta-2-thienylalanine (B2TA) [27-30]). Both BMAA and MSX significantly inhibit cyanobacterial growth under nitrogen-replete conditions [28]. It was found that MSX inhibits the activity of the enzyme glutamine synthetase (GS) and thus MSX derepresses mature heterocyst formation in the presence of nitrogen $[27,28]$. AzaTrp and B2TA do not inhibit GS activity, but azaTrp suppresses the activity of glutamine oxoglutarate aminotransferase (GOGAT), that leads to the accumulation of 2-oxoglutarate (2-OG) in the medium, which participates in signaling a response to nitrogen deprivation and in formation of heterocysts [27-29]. However, in contrast to BMAA and B2TA, the non-proteinogenic amino acids MSX and azaTrp induce formation of functional heterocysts $[27,28]$. 
So far, information about the mechanisms of non-proteinogenic amino acids effects on heterocyst formation is scarce. From our previous research, we know that BMAA suppresses genes involved in heterocyst formation and functionality under conditions of nitrogen deprivation [19]. In this study we found that heterocyst-like cells are formed in cyanobacteria due to the presence of BMAA in a nitrogen-rich medium, so we asked a question: does BMAA presence change the specific heterocyst gene expression in the nitrogen-grown cells of Anabaena 7120? To answer this question quantitative PCR was applied.

\subsection{BMAA Induces Heterocyst-Specific Gene Expression in Anabaena 7120 under Repressive Conditions}

Heterocysts of cyanobacteria are highly specialized cells for the process of nitrogen fixation. During nitrogen deprivation, cell differentiation is initiated by nitrogen deficiency in the growth medium. Cyanobacterial cell differentiation is an energy-consuming and finely-regulated, complex process $[20,31,32]$. Therefore, heterocyst formation normally is repressed in cyanobacteria in the nitrogen-replete growth medium [33] (Figure 1B,D). Since the addition of BMAA leads to the formation of heterocyst-like cells in Anabaena 7120 under repressive conditions, we used reverse transcription quantitative PCR (RT-qPCR) (Table 2) to estimate the transcription activity levels of several genes, involved in heterocyst formation and nitrogen assimilation. We discovered that the expression of heterocyst-specific genes (het $R$, hep $A, n i f H)$ and genes participating in nitrogen metabolism $(g \ln A$ and gltS) significantly increased compared to the control after $48 \mathrm{~h}$ of incubation in the presence of $20 \mu \mathrm{M}$ BMAA in the BG11 $\mathrm{N}_{\mathrm{N}}$ medium with sodium nitrate (Table 2). Note, the dark non-fluorescent heterocyst-like cells could be found also after $48 \mathrm{~h}$ of cyanobacterial growth in the presence of BMAA.

Table 2. Reverse transcription quantitative polymerase chain reaction (RT-qPCR) analysis of the nitrogen-regulated gene expression in Anabaena 7120 in the absence (control) or in the presence of BMAA $(20 \mu \mathrm{M})$ after $4,8,24,48$ and $96 \mathrm{~h}$ of BMAA treatment in nitrate-containing medium ${ }^{1}$.

\begin{tabular}{|c|c|c|c|c|c|c|c|}
\hline \multirow{2}{*}{ Gene } & \multirow{2}{*}{ Product } & & \multicolumn{5}{|c|}{ Relative Ratio in $\log _{2}$} \\
\hline & & & $4 \mathrm{~h}$ & $8 \mathrm{~h}$ & $24 \mathrm{~h}$ & $48 \mathrm{~h}$ & $96 \mathrm{~h}$ \\
\hline \multirow{2}{*}{ het $R$} & \multirow{2}{*}{ HetR, Heterocyst differentiation protein } & Control & $-2.33 \pm 0.02$ & $0.64 \pm 0.23$ & $-1.03 \pm 0.19$ & $0.09 \pm 0.07$ & $0.15 \pm 0.06$ \\
\hline & & BMAA & $-2.26 \pm 0.32$ & $0.45 \pm 0.41$ & $-1.29 \pm 0.22$ & $3.35 \pm 0.38$ & $0.36 \pm 0.22$ \\
\hline \multirow{2}{*}{ hepA } & \multirow{2}{*}{ HepA, Heterocyst differentiation protein } & Control & $-0.53 \pm 0.06$ & $0.66 \pm 0.21$ & $-0.06 \pm 0.13$ & $0.09 \pm 0.07$ & $0.15 \pm 0.06$ \\
\hline & & BMAA & $1.35 \pm 0.05$ & $3.87 \pm 0.36$ & $1.83 \pm 0.23$ & $3.35 \pm 0.38$ & $0.36 \pm 0.22$ \\
\hline \multirow{2}{*}{$n t c A$} & \multirow{2}{*}{$\begin{array}{l}\text { NtcA, Nitrogen-responsive regulatory } \\
\text { protein }\end{array}$} & Control & $-2.01 \pm 0.01$ & $2.50 \pm 0.60$ & $-1.35 \pm 0.11$ & $-0.12 \pm 0.09$ & $-0.65 \pm 0.27$ \\
\hline & & BMAA & $-1.36 \pm 0.67$ & $2.30 \pm 0.35$ & $-0.53 \pm 0.10$ & $1.31 \pm 0.27$ & $0.88 \pm 0.22$ \\
\hline \multirow{2}{*}{ nifH } & \multirow{2}{*}{ Nitrogenase subunit } & Control & $-0.39 \pm 0.07$ & $1.37 \pm 0.63$ & $1.47 \pm 0.68$ & $0.30 \pm 0.50$ & $3.18 \pm 2.82$ \\
\hline & & BMAA & $0.50 \pm 0.08$ & $3.44 \pm 0.11$ & $2.62 \pm 0.07$ & $6.57 \pm 1.43$ & $4.82 \pm 0.58$ \\
\hline \multirow{2}{*}{$g \ln A$} & \multirow{2}{*}{ Glutamine synthetase } & Control & $1.51 \pm 0.56$ & $-0.56 \pm 0.05$ & $2.22 \pm 0.95$ & $0.19 \pm 0.16$ & $-2.60 \pm 0.17$ \\
\hline & & BMAA & $1.80 \pm 0.04$ & $-0.67 \pm 0.99$ & $2.17 \pm 0.67$ & $2.70 \pm 0.15$ & $1.02 \pm 0.11$ \\
\hline \multirow{2}{*}{ glts } & \multirow{2}{*}{ Glutamine-oxoglutarate-aminotransferase } & Control & $-1.66 \pm 0.58$ & $1.23 \pm 0.15$ & $-1.14 \pm 0.40$ & $-0.24 \pm 0.03$ & $0.65 \pm 0.17$ \\
\hline & & BMAA & $-1.95 \pm 0.39$ & $0.67 \pm 0.28$ & $-0.13 \pm 0.01$ & $2.17 \pm 0.16$ & $2.17 \pm 0.12$ \\
\hline \multirow{2}{*}{ nirA } & \multirow{2}{*}{ Nitrite reductase } & Control & $-0.65 \pm 0.16$ & $1.40 \pm 0.16$ & $-0.67 \pm 0.26$ & $-1.51 \pm 0.16$ & $-4.54 \pm 0.07$ \\
\hline & & BMAA & $-1.10 \pm 0.28$ & $1.63 \pm 0.19$ & $-0.90 \pm 0.26$ & $-1.18 \pm 0.18$ & $-2.87 \pm 0.15$ \\
\hline
\end{tabular}

${ }^{1}$ Fold changes in gene expression are reported as $\log _{2}$ values. Each sample was measured in triplicate, and the standard deviation is indicated by error bars. Values were normalized to the $\operatorname{rp} B$ transcript level. The expression of the "housekeeping" gene $r n p B$ was not affected by the action of BMAA (data not shown). Significant differences of transcript levels between control and treated samples are shown inbold $(p<0.05)$ and were tested by Student's $t$-test.

Protein HetR interacts with the promoter of the hepA gene and regulates its expression during nitrogen step-down [34]. In the absence of BMAA, the hetR gene was not expressing in Anabaena 7120 (Table 2). Surprisingly, under BMAA treatment, the hetR gene expression was significantly upregulated within $48 \mathrm{~h}$ (Table 2). In a study by Buikema and Haselkorn [35] the presence of heterocyst-liked cells was reported in a wild type of Anabaena 7120 carrying a plasmid containing the hetR region, encoding HetR protein, when grown in the presence of nitrate. As in our study, the culture with heterocyst-like cells did not show any nitrogen fixation activity according to acetylene reduction assay (ARA) [35]. Under nitrogen depleted growth conditions the hepA expression follows after the hetR expression 
in proheterocysts $[20,32,36]$. In the control sample, as expected, the expression of both genes, hepA and hetR, was repressed (Table 2). In contrast, in the presence of BMAA, hepA gene was upregulated already after four hours of BMAA treatment (Table 2). The products of the het $R$ and hepA genes are required for heterocyst formation; thus, unpredictable induction of the transcription of these genes could be an explanation as to why a cyanobacterium forms heterocyst-like cells in the presence of BMAA (Figure 1C).

The nifHDK operon transcription is required at the final stages of heterocyst maturation, when subunits of nitrogenase enzyme have to be synthesized [37]. We found that nifH gene expression under BMAA treatment was upregulated in repressive conditions in comparison with the control sample (Table 2). However, such unexpected nifH gene expression in the presence of both nitrate and BMAA did not provide conditions for active nitrogenase enzyme synthesis, since the heterocyst-like cells did not show any of the acetylene reduction activity (Table 1 ).

The $n t c A$ gene encodes a global regulatory protein of nitrogen metabolism, a transcription factor NtcA [38]. BMAA did not significantly affect the expression of this gene during the first $24 \mathrm{~h}$ compared to control sample. Its expression increased slightly after $48 \mathrm{~h}$ of incubation with BMAA.

Thus, in the presence of BMAA the cell control of key genes' expression unexpectedly changed. The genes, involved in the heterocyst and nitrogenase formation, are supposed to be silent under nitrogen-replete conditions; however, they are activated, what leads to heterocyst-like non-functional cells formation.

\subsection{BMAA Induces glnA and gltS Gene Expression in Anabaena 7120 under Repressive Conditions}

We examined the BMAA action also on the expression of three genes $(g \ln A, g l t S$ and $\operatorname{nir} A)$, whose products are important enzymes of cyanobacteria nitrogen metabolism (Table 2). The $g \ln A$ and $g l t S$ genes encoded glutamine synthetase (GS) and glutamate synthase (GOGAT), respectively. These enzymes are key players in nitrogen assimilation [39-41]. In our experiments, the expression of the $g \ln A$ and $g l t S$ genes increased significantly after $48 \mathrm{~h}$ in the BMAA-treated sample during growth in a nitrate-containing medium. In addition, the transcript levels of the nir $A$ gene did not noticeably change after the BMAA treatment (Table 2). The product of the nirA gene is the nitrite reductase, one of the main enzymes implicated in nitrate assimilation [42,43]. Anabaena 7120 was more resistant to higher concentrations of BMAA in the ammonium-containing medium than in the medium with nitrate (Figure 3). Thus, it could be proposed that the possible BMAA target could be related to the functionality of enzymes involved in nitrate assimilation or to expression of narB and nir $A$ genes encoding nitrate and nitrite reductase, respectively [44]. However, our results did not support this statement, at least not with respect to nirA gene expression (Table 2).

The unexpected expression of heterocyst specific genes in repressive conditions indicates a false nitrogen depletion signal in cyanobacterial cells. What kind of the nitrogen limitation signal could arise in the cyanobacterial cells in the presence of BMAA in the nitrogen-containing growth medium? It is known that the 2-OG is involved in the signaling response to nitrogen stress [31,32,45]. Moreover, frequency of heterocyst rises with the increase of 2-OG concentration in the growth medium [45]. It is also known that 2-OG is involved and metabolized via the GS/GOGAT pathway [46]. We can hypothesize that BMAA, as an analogue of glutamate $[25,47]$, can compete with glutamate for binding to the GS enzyme. Therefore, GS/GOGAT cycle activity could be impaired by the addition of BMAA. Recently researchers found that this cyanotoxin affects the metabolism of nitrogen in diatoms via the GS/GOGAT pathway, possibly through the inhibition of ammonium assimilation [48]. Thus, the disturbance of the GS/GOGAT pathway by BMAA could lead to accumulation of the signal molecule 2-OG. In its turn, 2-OG stimulates the DNA-binding activity of nitrogen global regulator NtcA [40,49] and triggers the expression of the genes involved in heterocyst formation in restrictive conditions. Recently it was reported that BMAA disturbs metabolism of amino acids (alanine, aspartate and glutamate) in eukaryotic cells [50,51]. Hence, if BMAA interferes in these pathways 
in cyanobacteria, it could affect nitrogen control that causes improper regulation of gene expression. Verification of this hypothesis requires further exciting studies.

Summarizing, we can conclude that BMAA influences nitrogen metabolism and gene expression of filamentous nitrogen-fixing cyanobacteria, which leads to disturbances in their development. In particular, under conditions of nitrogen starvation BMAA suppresses the formation of heterocysts, and under conditions of nitrogen excess it induces a signal of nitrogen deficiency in some way. This, in turn, leads to the expression of genes that are usually silent under nitrogen-replete conditions and to the formation of heterocyst-like cells. New experiments with the application of mutagenesis and biochemistry methods can help us to understand the details and clarify the role of BMAA in the metabolism of cyanobacteria.

From an ecological point of view, future experiments on the joint cultivation (mixed cultures) of different cyanobacteria species, or cyanobacteria and diatoms, followed by metabolites monitoring, are great of interest. Cyanobacteria and algae are in complex relationships, including symbiosis and competition [52-57]. Allelopathic functions of other cyanobacterial toxin, microcystin, have been investigated in several studies [58-63]. It would be interesting to find out the possible role of BMAA in allelopathy.

\section{Conclusions}

We found an unusual regulatory effect of BMAA that induced the transcription of several essential genes implicated in heterocyst formation, nitrogen fixation and nitrogen assimilation in Anabaena sp. PCC 7120. This BMAA regulatory effect leads to the formation of non-functional dark non-fluorescent heterocyst-like cells under repressive conditions. The induction of heterocyst-like cells was also observed in two different Nostoc strains. The regulatory effect of BMAA could be canceled by glutamate addition. Data obtained are important for further fundamental studies of the regulatory role of cyanobacterial secondary metabolites.

\section{Materials and Methods}

\subsection{Cyanobacterial Strain and Cultivation Conditions}

Cyanobacterium Anabaena sp. PCC 7120 (in short Anabaena 7120) was received from the Pasteur Culture collection of Cyanobacteria, Paris, France.

Nostoc sp. strain 8963 and Nostoc punctiforme PCC 73102 (ATCC 29133) are symbiotic isolates from, respectively, Gunnera prorepens [1] and cycad Macrozamia sp. [64].

Filamentous nitrogen-fixing cyanobacteria Anabaena 7120, Nostoc punctiforme PCC 73102, Nostoc sp. strain 8963 were grown in $100 \mathrm{~mL}$ Erlenmeyer flasks containing $25 \mathrm{~mL}$ of BG11 liquid medium [64]. We used nitrogen-free medium $\left(B G 11_{0}\right)$ or medium $\left(B G 11_{N}\right)$ containing $17.6 \mathrm{mM}$ sodium nitrate or $5 \mathrm{mM}$ ammonium chloride. Cultures were grown at $25^{\circ} \mathrm{C}$ on a shaker at $63 \mathrm{rpm}$ and with continuous shaking at a light intensity of $18 \mu \mathrm{mol}$ photons $\mathrm{m}^{-2} \mathrm{~s}^{-1}$.

\subsection{Chlorophyll A Measurements}

Concentration of Chla was measured as described in [19]. Samples were collected during six days of Anabaena 7120 growth with BMAA. Cells in the aliquots of cyanobacterial suspensions were degraded by centrifugation, followed by vortexing in $90 \%$ ethanol for $\mathrm{Chl} a$ release into supernatant. Measurements were conducted spectrophotometrically at $665 \mathrm{~nm}$ and $750 \mathrm{~nm}$ using Ultrospec 3000 (Pharmacia Biotech, Cambridge, UK). Concentration of Chla was calculated according to [65].

\subsection{Nitrogenase Activity Measurements}

The nitrogenase activity was measured using ARA combined with gas chromatography according $[8,19]$ with some differences described below and calculated as amount of acetylene $\left(\mathrm{C}_{2} \mathrm{H}_{2}\right)$ reduced to ethylene ( $\mathrm{nmol} \mathrm{C}_{2} \mathrm{H}_{4} \mu \mathrm{g} \mathrm{Chl} \mathrm{a}{ }^{-1} \mathrm{~h}^{-1}$ ) produced according to Capone and 
Montoya [26]. We collected three aliquots of cell suspension from the each flask into glass vials to provide three technical replicates; $1 \mathrm{~mL}$ of the gas phase from each vial was analyzed for ethylene content using gas chromatography (Kristall 2000, RPC «Meta-Chrom», Russia, Mari El Republic, Yoshkar-Ola) with a flame ionization detector (GC-FID). The amount of ethylene was measured with the following device parameters: column length $1 \mathrm{~m}$, diameter $3 \mathrm{~mm}$, filler Porapak N 80/100 mesh (Sigma-Aldrich, Darmstadt, Germany), column temperature $+60{ }^{\circ} \mathrm{C}$, detector temperature $+160{ }^{\circ} \mathrm{C}$, evaporator temperature $+100{ }^{\circ} \mathrm{C}$, flow rate of carrier gas $\left(\mathrm{N}_{2}\right) 50 \mathrm{~mL} \mathrm{~min}^{-1}$, air-280 mL min ${ }^{-1}$, hydrogen-28 mL min ${ }^{-1}$ ). Peaks were displayed with the software NetChrom V 2.1 (RPC «Meta-Chrom», Russia, Mari El Republic, Yoshkar-Ola). Concentrations of Chla were used for nitrogenase activity normalization. All experiments were performed in five biological repeats.

\subsection{Fluorescence Microscopy}

The control and BMAA treated cells of cyanobacteria were investigated microscopically after 48 , 72 and $96 \mathrm{~h}$ after $20 \mu \mathrm{M}$ BMAA additions. The observations were performed by using a fluorescence microscope Axiovert 200M and Plan-Neofluar (Carl Zeiss GmbH, Jena, Germany). Measurements were made using the Microscope Software AxioVision 4.5. Heterocyst-like cells' frequency was defined as the percentage of heterocyst-like cells of the total cyanobacterial cell population. This was determined by counting the heterocyst-like cells and vegetative cells numbers along the filaments. The total number of cells counted was no less than 650 cells per sample.

\subsection{RNA Extraction and Reverse Transcription Quantitative PCR (RT-qPCR)}

Total RNA isolation from Anabaena 7120 was performed by using the Trizol (Invitrogen, CA, USA) reagent and cDNA synthesis was conducted by H-minus Mu-MLV reverse transcriptase $(200 \mathrm{U} / \mu \mathrm{L})$ (Thermo Scientific, \#EP0451, Waltham, MA, USA) treatment as described in [19]. To quantify expression levels of target genes (Table 2), RT-qPCR was performed as described in [19]. The gene-specific primers (Table 3) [19] were synthesized at the Syntol Company (Moscow, Russia). SYBR Green I dye (Invitrogen) was used for amplicon staining. The comparative $-2^{\Delta \Delta C t}$ method was used to calculate and analyze the relative gene expression [66]. All Ct values were normalized to rnpB [67].

Table 3. Primers used for RT-qPCR.

\begin{tabular}{ccc}
\hline Primer & Sequence $\left(\mathbf{5}^{\prime} \rightarrow \mathbf{3}^{\prime}\right)$ & Reference \\
\hline nifH-F & CTATGCCTATCCGTGAAGG & {$[19]$} \\
nifH-R & CCAAGTTCATGATTAACTCGTC & {$[19]$} \\
hetR-F & AGTTACCCAGCAATCTTCCC & {$[19]$} \\
hetR-R & ATAGAAGGGCATTCCCCAAG & {$[19]$} \\
ntcA-F & GAGCTTTTCCTCCTGTTGTC & {$[19]$} \\
ntcA-R & ACCTATCCGACTTGTTTCCT & {$[19]$} \\
glnA-F & GGTGATACAGCCTTCTTTGG & {$[19]$} \\
glnA-R & CTTGGAAAGAATCTGTGGGG & {$[19]$} \\
nirA-F & CCAACAAAGGAGAAGGCAAT & {$[19]$} \\
nirA-R & AGAAACCACCAACTAACACG & {$[19]$} \\
hepA-F & TTCGGGTGAACTCATTAATACG & {$[19]$} \\
hepA-R & TTCTCTGACTCGCTTATTCAG & {$[19]$} \\
gltS-F & TAGAACATCGGGGTGGTTGT & {$[19]$} \\
gltS-R & CTACTCGCCAGCCCAATAC & {$[19]$} \\
rnpB-F & ACTGATTTGAGGAAAGTCCG & {$[67]$} \\
rnpB-R & CTTTGCACCCTTACCAAGAG & {$[67]$} \\
\hline
\end{tabular}

\subsection{Statistical Analysis}

Three or five biological replicates were performed and the average with standard deviation was calculated for all data. Three or four technical repeats were performed within each measurement. The Student's $t$-test was used to determine the statistical significance determination. The significance of 
mRNA level change was identified by using a $t$-test with multiple and Benjamini-Hochberg adjustment for $p$-values [68]. One-way analysis of variance (ANOVA) with the Benjamini-Hochberg correction was applied for time groups' comparison. Pairwise comparison was made using Tukey's test. The R statistical software program was applied for the analyses.

Author Contributions: Conceptualization, O.A.K.; Data curation, A.A.P.; Formal analysis, A.A.P. and T.A.S.; Funding acquisition, V.M.G. and O.A.K.; Investigation, A.A.P., T.A.S., N.V.K. and O.A.K.; Methodology, U.R. and O.A.K.; Project administration, O.A.K.; Resources, V.M.G. and O.A.K.; Supervision, V.M.G. and O.A.K.; Validation, A.A.P. and T.A.S.; Visualization, A.A.P.; Writing-original draft, A.A.P. and O.A.K.; Writing-review \& editing, U.R. and O.A.K.

Funding: This work was funded by the Russian Foundation for Basic Research (grant\#17-04-00412).

Acknowledgments: This work was supported by the Russian Foundation for Basic Research (grant \# 17-04-00412). We are very grateful to Ms. Nina A. Safronova for her valuable suggestions and comments.

Conflicts of Interest: The authors declare that they have no conflicts of interest.

\section{References}

1. Cox, P.A.; Banack, S.A.; Murch, S.J.; Rasmussen, U.; Tien, G.; Bidigare, R.R.; Metcalf, J.S.; Morrison, L.F.; Codd, G.A.; Bergman, B. Diverse taxa of cyanobacteria produce beta- $N$-methylamino-L-alanine, a neurotoxic amino acid. Proc. Natl. Acad. Sci. USA 2005, 102, 5074-5078. [CrossRef] [PubMed]

2. Banack, S.A.; Johnson, H.E.; Cheng, R.; Cox, P.A. Production of the neurotoxin BMAA by a marine cyanobacterium. Mar. Drugs 2007, 5, 180-196. [CrossRef] [PubMed]

3. Esterhuizen, M.; Downing, T.G. $\beta$-N-methylamino-L-alanine (BMAA) in novel South African cyanobacterial isolates. Ecotoxicol. Environ. Saf. 2008, 71, 309-313. [CrossRef] [PubMed]

4. Metcalf, J.S.; Banack, S.A.; Lindsay, J.; Morrison, L.F.; Cox, P.A.; Codd, G.A. Co-occurrence of $\beta$ - $N$-methylamino-L-alanine, a neurotoxic amino acid with other cyanobacterial toxins in British waterbodies, 1990-2004. Environ. Microbiol. 2008, 10, 702-708. [CrossRef] [PubMed]

5. Spácil, Z.; Eriksson, J.; Jonasson, S.; Rasmussen, U.; Ilag, L.L.; Bergman, B. Analytical protocol for identification of BMAA and DAB in biological samples. Analyst 2009, 135, 127-132. [CrossRef] [PubMed]

6. Cox, P.A.; Banack, S.A.; Murch, S.J. Biomagnification of cyanobacterial neurotoxins and neurodegenerative disease among the Chamorro people of Guam. Proc. Natl. Acad. Sci. USA 2003, 100, 13380-13383. [CrossRef] [PubMed]

7. Murch, S.J.; Cox, P.A.; Banack, S.A.; Steele, J.C.; Sacks, O.W. Occurrence of $\beta$-methylamino-l-alanine (BMAA) in ALS/PDC patients from Guam. Acta Neurol. Scand. 2004, 110, 267-269. [CrossRef] [PubMed]

8. Berntzon, L.; Ronnevi, L.-O.; Bergman, B.; Eriksson, J. Detection of BMAA in the human central nervous system. Neuroscience 2015, 292, 137-147. [CrossRef] [PubMed]

9. Jonasson, S.; Eriksson, J.; Berntzon, L.; Spácil, Z.; Ilag, L.L.; Ronnevi, L.O.; Rasmussen, U.; Bergman, B. Transfer of a cyanobacterial neurotoxin within a temperate aquatic ecosystem suggests pathways for human exposure. Proc. Natl. Acad. Sci. USA 2010, 107, 9252-9257. [CrossRef] [PubMed]

10. Jiang, L.; Eriksson, J.; Lage, S.; Jonasson, S.; Shams, S.; Mehine, M.; Ilag, L.L.; Rasmussen, U. Diatoms: A novel source for the neurotoxin BMAA in aquatic environments. PLoS ONE 2014, 9, e84578. [CrossRef] [PubMed]

11. Lage, S.; Costa, P.R.; Moita, T.; Eriksson, J.; Rasmussen, U.; Rydberg, S.J. BMAA in shellfish from two Portuguese transitional water bodies suggests the marine dinoflagellate Gymnodinium catenatum as a potential BMAA source. Aquat. Toxicol. 2014, 152, 131-138. [CrossRef] [PubMed]

12. Scott, L.L.; Downing, S.; Phelan, R.R.; Downing, T.G. Environmental modulation of microcystin and $\beta-N$-methylamino-L-alanine as a function of nitrogen availability. Toxicon 2014, 87, 1-5. [CrossRef] [PubMed]

13. Pablo, J.; Banack, S.A.; Cox, P.A.; Johnson, T.E.; Papapetropoulos, S.; Bradley, W.G.; Buck, A.; Mash, D.C. Cyanobacterial neurotoxin BMAA in ALS and Alzheimer's disease. Acta Neurol. Scand. 2009, 120, $216-225$. [CrossRef] [PubMed]

14. Popova, A.A.; Koksharova, O.A. Neurotoxic non-proteinogenic amino acid $\beta$ - $N$-methylamino-L-alanine and its role in biological systems. Biochemistry 2016, 81, 794-805. [CrossRef] [PubMed] 
15. Nunn, P.B.; Codd, G.A. Metabolic solutions to the biosynthesis of some diaminomonocarboxylic acids in nature: Formation in cyanobacteria of the neurotoxins 3-N-methyl-2,3-diaminopropanoic acid (BMAA) and 2,4-diaminobutanoic acid (2,4-DAB). Phytochemistry 2017, 144, 253-270. [CrossRef] [PubMed]

16. Downing, S.; Banack, S.A.; Metcalf, J.S.; Cox, P.A.; Downing, T.G. Nitrogen starvation of cyanobacteria results in the production of $\beta-N$-methylamino-L-alanine. Toxicon 2011, 58, 187-194. [CrossRef] [PubMed]

17. Downing, T.G.; Phelan, R.R.; Downing, S. A potential physiological role for cyanotoxins in cyanobacteria of arid environments. J. Arid Environ. 2015, 112, 147-151. [CrossRef]

18. Berntzon, L.; Erasmie, S.; Celepli, N.; Eriksson, J.; Rasmussen, U.; Bergman, B. BMAA inhibits nitrogen fixation in the cyanobacterium Nostoc sp. PCC 7120. Mar. Drugs 2013, 11, 3091-3108. [CrossRef] [PubMed]

19. Popova, A.A.; Rasmussen, U.; Semashko, T.A.; Govorun, V.M.; Koksharova, O.A. Stress effects of cyanotoxin $\beta$-methylamino-L-alanine (BMAA) on cyanobacterial heterocyst formation and functionality. Environ. Microbiol. Rep. 2018, 10, 369-377. [CrossRef] [PubMed]

20. Flores, E.; Picossi, S.; Valladares, A.; Herrero, A. Transcriptional regulation of development in heterocyst-forming cyanobacteria. Biochim. Biophys. Acta 2018. [CrossRef] [PubMed]

21. Thomas, J. Absence of the pigments of photosystem II of photosynthesis in heterocysts of a blue-green alga. Nature 1970, 228, 181-183. [CrossRef] [PubMed]

22. Ferimazova, N.; Felcmanová, K.; Šetlíková, E.; Küpper, H.; Maldener, I.; Hauska, G.; Šedivá, B.; Práš, O. Regulation of photosynthesis during heterocyst differentiation in Anabaena sp. strain PCC 7120 investigated in vivo at single-cell level by chlorophyll fluorescence kinetic microscopy. Photosynth. Res. 2013, 116, 79-91. [PubMed]

23. Nozue, S.; Mukuno, A.; Tsuda, Y.; Shiina, T.; Terazima, M.; Kumazaki, S. Characterization of thylakoid membrane in a heterocystous cyanobacterium and green alga with dual-detector fluorescence lifetime imaging microscopy with a systematic change of incident laser power. Biochim. Biophys. Acta 2016, 1857, 46-59. [CrossRef] [PubMed]

24. Kumar, K.; Mella-Herrera, R.A.; Golden, J.W. Cyanobacterial heterocysts. Cold Spring Harb. Perspect. Biol. 2010, 2, A000315. [CrossRef] [PubMed]

25. Weiss, J.H.; Choi, D.W. $\beta$-N-methylamino-L-alanine neurotoxicity: Requirement for bicarbonate as a cofactor. Science 1988, 241, 973-975. [CrossRef] [PubMed]

26. Capone, D.G.; Montoya, J.P. Nitrogen Fixation and Denitrification. In Marine Microbiology; Paul, J.H., Ed.; Academic Press: London, UK, 2001; pp. 501-515.

27. Stacey, G.; Van Baalen, C.; Tabita, F.R. Isolation and characterization of a marine Anabaena sp. capable of rapid growth on molecular nitrogen. Arch. Microbiol. 1977, 114, 197-201. [CrossRef]

28. Rogerson, A.C. Modifiers of heterocyst repression and spacing and formation of heterocysts without nitrogenase in the cyanobacterium Anabaena variabilis. J. Bacteriol. 1979, 140, 213-219. [PubMed]

29. Chen, C.H.; Van Baalen, C.; Tabita, F.R. Nitrogen starvation mediated by DL-7-azatryptophan in the cyanobacterium Anabaena sp. strain CA. J. Bacteriol. 1987, 169, 1107-1113. [CrossRef] [PubMed]

30. Mishra, A.K. MSX-resistant mutants of Anabaena 7120 with derepressed heterocyst development and nitrogen fixation. World J. Microbial. Biotechnol. 2003, 19, 675-680. [CrossRef]

31. Zhang, C.C.; Laurent, S.; Sakr, S.; Peng, L.; Bédu, S. Heterocyst differentiation and pattern formation in cyanobacteria: A chorus of signals. Mol. Microbiol. 2006, 59, 367-375. [CrossRef] [PubMed]

32. Muro-Pastor, A.M.; Hess, W.R. Heterocyst differentiation: From single mutants to global approaches. Trends Microbiol. 2012, 20, 548-557. [CrossRef] [PubMed]

33. Sarma, T.A. Handbook of Cyanobacteria; CRC Press: Boca Raton, FL, USA, 2012.

34. Videau, P.; Ni, S.; Rivers, O.S.; Ushijima, B.; Feldmann, E.A.; Cozy, L.M.; Kennedy, M.A.; Callahan, S.M. Expanding the direct HetR regulon in Anabaena sp. strain PCC 7120. J. Bacteriol. 2014, 196, 1113-1121. [CrossRef] [PubMed]

35. Buikema, W.J.; Haselkorn, R. Characterization of a gene controlling heterocyst differentiation in the cyanobacterium Anabaena 7120. Genes Dev. 1991, 5, 321-330. [CrossRef] [PubMed]

36. Black, T.A.; Cai, Y.; Wolk, C.P. Spatial expression and autoregulation of hetR, a gene involved in the control of heterocyst development in Anabaena. Mol. Microbiol. 1993, 9, 77-84. [CrossRef] [PubMed]

37. Golden, J.W.; Whorff, L.L.; Wiest, D.R. Independent regulation of nifHDK operon transcription and DNA rearrangement during heterocyst differentiation in the cyanobacterium Anabaena sp. strain PCC 7120. J. Bacteriol. 1991, 173, 7098-7105. [CrossRef] [PubMed] 
38. Herrero, A.; Muro-Pastor, A.M.; Valladares, A.; Flores, E. Cellular differentiation and the NtcA transcription factor in filamentous cyanobacteria. FEMS Microbiol. Rev. 2004, 28, 469-487. [CrossRef] [PubMed]

39. Tumer, N.E.; Robinson, S.J.; Haselkorn, R. Different promoters for the Anabaena glutamine synthetase gene during growth using molecular or fixed nitrogen. Nature 1983, 306, 337-342. [CrossRef]

40. Frías, J.E.; Flores, E.; Herrero, A. Requirement of the regulatory protein NtcA for the expression of nitrogen assimilation and heterocyst development genes in the cyanobacterium Anabaena sp. PCC 7120. Mol. Microbiol. 1994, 14, 823-832. [CrossRef] [PubMed]

41. Thiel, T. Nitrogen fixation in heterocyst-forming cyanobacteria. In Genetics and Regulation of Nitrogen Fixation in Free-Living Bacteria; Klipp, W., Masepohl, B., Gallon, J.R., Newton, W.E., Eds.; Kluwer Academic Publishers: Dordrecht, The Netherlands, 2005; pp. 73-111.

42. Luque, I.; Flores, E.; Herrero, A. Nitrite reductase gene from Synechococcus sp. PCC 7942: Homology between cyanobacterial and higher-plant nitrite reductases. Plant Mol. Biol. 1993, 21, 1201-1205. [CrossRef] [PubMed]

43. Cai, Y.; Wolk, C.P. Nitrogen deprivation of Anabaena sp. strain PCC 7120 elicits rapid activation of a gene cluster that is essential for uptake and utilization of nitrate. J. Bacteriol. 1997, 179, 258-266. [CrossRef] [PubMed]

44. Rubio, L.M.; Herrero, A.; Flores, E. A cyanobacterial narB gene encodes a ferredoxin-dependent nitrate reductase. Plant Mol. Biol. 1996, 4, 845-850. [CrossRef]

45. Li, J.-H.; Laurent, S.; Konde, V.; Bedu, S.; Zhang, C.C. An increase in the level of 2-oxoglutarate promotes heterocyst development in the cyanobacterium Anabaena sp. strain PCC 7120. Microbiology 2003, 149, 3257-3263. [CrossRef] [PubMed]

46. Muro-Pastor, M.I.; Reyes, J.C.; Florencio, F.J. Ammonium assimilation in cyanobacteria. Photosynth. Res. 2005, 83, 135-150. [CrossRef] [PubMed]

47. Brownson, D.M.; Mabry, T.J.; Leslie, S.W. The cycad neurotoxic amino acid, $\beta$-N-methylamino-L-alanine (BMAA), elevates intracellular calcium levels in dissociated rat brain cells. J. Ethnopharmacol. 2002, 82, 159-167. [CrossRef]

48. Lage, S.; Ström, L.; Godhe, A.; Rydberg, S. The effect of exogenous $\beta$-N-methylamino-L-alanine (BMAA) on the diatoms Phaeodactylum tricornutum and Thalassiosira weissflogii. Harmful Algae 2016, 58, 85-92. [CrossRef] [PubMed]

49. Wei, T.F.; Ramasubramanian, T.S.; Golden, J.W. Anabaena sp. strain PCC 7120 ntcA gene required for growth on nitrate and heterocyst development. J. Bacteriol. 1994, 176, 4473-4482. [CrossRef] [PubMed]

50. Nunn, P.B.; Ponnusamy, M. $\beta-N$-methylaminoalanine (BMAA): Metabolism and metabolic effects in model systems and in neural and other tissues of the rat in vitro. Toxicon 2009, 54, 85-94. [CrossRef] [PubMed]

51. Engskog, M.K.R.; Ersson, L.; Haglöf, J.; Arvidsson, T.; Pettersson, C.; Brittebo, E. $\beta$-N-Methylaminol-L-alanine (BMAA) perturbs alanine, aspartate and glutamate metabolism pathways in human neuroblastoma cells as determined by metabolic profiling. Amino Acids 2017, 49, 905-919. [CrossRef] [PubMed]

52. Reynolds, C.S. Structural, dynamic and energetic differences among biotic communities dominated by macrophytes, planktonic algae and cyanobacteria. Water Sci. Technol. 1995, 32, 1-23. [CrossRef]

53. Horn, H.; Uhlmann, D. Competitive growth of blue-greens and diatoms (Fragilaria) in the Saidenbach Reservoir, Saxony. Water Sci. Technol. 1995, 32, 77-88. [CrossRef]

54. Watermann, F.; Hillebrand, H.; Gerdes, G.; Krumbein, W.E.; Sommer, U. Competition between benthic cyanobacteria and diatoms as influenced by different grain sizes and temperatures. Mar. Ecol. Prog. Ser. 1999, 187, 77-87. [CrossRef]

55. Van der Grinten, E.; Simis, S.G.H.; Barranguet, C.; Admiraal, W. Dominance of diatoms over cyanobacterial species in nitrogen-limited biofilms. Arch. Hydrobiol. 2004, 161, 99-112. [CrossRef]

56. Bruckner, C.G.; Rehm, C.; Grossart, H.P.; Kroth, P.G. Growth and release of extracellular organic compounds by benthic diatoms depend on interactions with bacteria. Environ. Microbiol. 2011, 13, 1052-1063. [CrossRef] [PubMed]

57. Amin, S.A.; Parker, M.S.; Armbrust, E.V. Interactions between Diatoms and Bacteria. Microbiol. Mol. Biol. Rev. 2012, 76, 667-684. [CrossRef] [PubMed]

58. Pflugmacher, S. Possible allelopathic effects of cyanotoxins, with reference to microcystin-LR, in aquatic ecosystems. Environ. Toxicol. 2002, 17, 407-413. [CrossRef] [PubMed]

59. Jang, M.H.; Ha, K.; Joo, G.-J.; Takamura, N. Toxin production ofcyanobacteria is increased by exposure to zooplankton. Freshw. Biol. 2003, 48, 1540-1550. [CrossRef] 
60. Jang, M.H.; Ha, K.; Takamura, N. Reciprocal allelopathic responses between toxic cyanobacteria (Microcystis aeruginosa) and duckweed (Lemna japonica). Toxicon 2007, 49, 727-733. [CrossRef] [PubMed]

61. Jang, M.H.; Jung, J.M.; Takamura, N. Changes in microcystin production in cyanobacteria exposed to zooplankton at different population densities and infochemical concentrations. Limnol. Oceanogr. 2007, 52, 1454-1466. [CrossRef]

62. Jang, M.H.; Ha, K.; Takamura, N. Microcystin production by Microcystis aeruginosa exposed to different stages of herbivorous zooplankton. Toxicon 2008, 51, 882-889. [CrossRef] [PubMed]

63. Ha, K.; Takamura, N.; Jang, M.H. Microcystin Production by Microcystis aeruginosa Exposed to Phytoplanktivorous and Omnivorous Fish at Different Kairomone Concentrations. Bull. Environ. Contam. Toxicol. 2009, 83, 761-765. [CrossRef] [PubMed]

64. Rippka, R.; Deruelles, J.; Waterbury, J.B.; Herdman, M.; Stanier, R.Y. Generic assignments, strain histories and properties of pure cultures of cyanobacteria. J. Gen. Microbiol. 1979, 111, 1-61. [CrossRef]

65. Talling, J.F.; Driver, D. Some problems in the estimation of chlorophyll- $a$ in phytoplankton, in primary productivity measurement, marine and freshwater. In U.S. Atomic Energy Commision Report No. TID-7633; Doty, M.S., Ed.; U.S. Atomic Energy Commision: Honolulu, HI, USA, 1961; pp. 142-146.

66. Livak, K.J.; Schmittgen, T.D. Analysis of relative gene expression data using real-time quantitative PCR and the 2(-Delta Delta C(T)). Methods 2001, 25, 402-408. [CrossRef] [PubMed]

67. Pinto, F.; Pacheco, C.C.; Ferreira, D.; Moradas-Ferreira, P.; Tamagnini, P. Selection of suitable reference genes for RT-qPCR analyses in cyanobacteria. PLoS ONE 2012, e34983. [CrossRef] [PubMed]

68. Benjamini, Y.; Hochberg, Y. Controlling the false discovery rate: A practical and powerful approach to multiple testing. J. R. Stat. Soc. 1995, 57, 289-300.

(C) 2018 by the authors. Licensee MDPI, Basel, Switzerland. This article is an open access article distributed under the terms and conditions of the Creative Commons Attribution (CC BY) license (http:/ / creativecommons.org/licenses/by/4.0/). 